\title{
Upper gastrointestinal haemorrhage in the non-European
}

\author{
S. GRIEVE, W. COOPER, B. FRASER, A. DUBB, S. GENTIN, H. KAVIN, \\ AND I. LAW \\ From the Coronation Hospital, Johannesburg, and the University of the Witwatersrand
}

SYNOPSIS An analysis of the 149 cases of haematemesis admitted to Coronation Hospital from January 1951, to September 1959, is presented. The commonest cause was found to be acute gastritis and gastric erosion. These cases were more common in males and usually followed on an alcoholic bout. These were in the main mild. Twenty-five cases associated with peptic ulceration were found, and the lesion occurred more commonly in males under the age of 40 . Duodenal ulcer was commoner than gastric ulcer. The incidence of haematemesis with peptic ulceration appears to be on the increase, the cause of which is not known. Cirrhosis of the liver is a frequent cause of haematemesis and carries a high mortality.

The difficulties of diagnosis and treatment of cases of gastrointestinal haemorrhage in the European have been well documented (Avery Jones, Read, and Stubbe, 1959). The problem is much greater in the non-European patient as the haemorrhage is usually the sole presenting feature, and clinical examination is in the majority of cases negative.

The routine followed in the Medical Division of this hospital is that the history and clinical findings are evaluated as accurately as possible. A surgical consultation is arranged if the patient is clinically anaemic. Complete haematological and biochemical studies, liver function tests, and sigmoidoscopy are carried out. Radiological examinations are performed as soon as possible, preferably within seven days in order to avoid the possibility of overlooking a rapidly healing ulcer. Stools and urines are examined for parasites. Gastroscopy is not routinely performed.

In a survey of the records of this hospital from 1951 to September 1959, 149 cases of gastrointestinal haemorrhage were found to have been admitted.

\section{TABLE I}

AETIOLOGICAL GROUPS

\begin{tabular}{lcc} 
& No. of Cases & Deaths \\
\hline Peptic ulcer & 25 & 2 \\
Acute gastritis and gastric erosions & 65 & 2 \\
Cirrhosis and oesophageal varices & 32 & 13 \\
Gastric malignancy and tumours & 7 & 1 \\
Otber causes & 7 & 4 \\
Total & 136 & 22
\end{tabular}

Thirteen of these cases were Indians and these are not included in the analysis (Table I).

\section{PEPTIC ULCERATION}

All cases (Table II) were proved either by radiography, laparotomy, or necropsy. It will be seen that duodenal ulcer occurs three times as commonly as gastric ulceration, i.e., 19 cases: 6 cases. Peptic ulceration occurs far more commonly in the younger age groups, $72 \%$ of the patients being under 40 . This applies to both duodenal and gastric ulcers although the figures for gastric ulcer are too small for any valid deduction to be made. The male sex is predominately affected: $80 \%$ of the cases were males. It will be seen from Table III that the number of cases is increasing, especially during the last nine months.

\section{ACUTE GASTRITIS AND GASTRIC EROSIONS}

The largest number of cases (Table IV) fell under this heading. Routine investigation proved completely negative, no cause for the bleeding being found. The severity of the bleeding varied considerably, the majority of the cases being mild. Two of these cases were subjected to gastrectomy owing to continued haematemesis and the pathological findings were (1) acute gastritis with haemorrhage into the mucosa and submucosa, and (2) phlegmonous gastritis. Two patients were admitted severely bled out and died shortly after admission. Permission for 
TABLE II

PEPTIC ULCERATION

\begin{tabular}{|c|c|c|c|c|c|c|c|c|c|c|c|}
\hline \multirow[t]{2}{*}{ Age Group (years) } & \multicolumn{2}{|l|}{ Under 30} & \multicolumn{2}{|l|}{$.30-39$} & \multicolumn{2}{|l|}{$40-49$} & \multicolumn{2}{|l|}{$50-59$} & \multicolumn{2}{|l|}{ Over 60} & \multirow[t]{2}{*}{ Total } \\
\hline & $\begin{array}{l}\text { Duodenal } \\
\text { Ulcer }\end{array}$ & $\begin{array}{l}\text { Gastric } \\
\text { Ulcer }\end{array}$ & $\begin{array}{l}\text { Duodenal } \\
\text { Ulcer }\end{array}$ & $\begin{array}{l}\text { Gastric } \\
\text { Ulcer }\end{array}$ & $\begin{array}{l}\text { Duodenal } \\
\text { Ulcer }\end{array}$ & $\begin{array}{l}\text { Gastric } \\
\text { Ulcer }\end{array}$ & $\begin{array}{l}\text { Duodenal } \\
\text { Ulcer }\end{array}$ & $\begin{array}{l}\text { Gastric } \\
\text { Ulcer }\end{array}$ & $\begin{array}{l}\text { Duodenal } \\
\text { Ulcer }\end{array}$ & $\begin{array}{l}\text { Gastric } \\
\text { Ulcer }\end{array}$ & \\
\hline Bantu males & 1 & 2 & 6 & 0 & 3 & 0 & 1 & 0 & 0 & $\mathbf{0}$ & 13 \\
\hline Bantu females & 2 & 1 & - & - & - & - & - & - & - & - & 3 \\
\hline Coloured males & 1 & 0 & 1 & 2 & 1 & 0 & 1 & 0 & 1 & 0 & 7 \\
\hline Coloured females & 1 & 1 & - & - & - & - & - & - & - & - & 2 \\
\hline
\end{tabular}

One case of pyloric stenosis was found.

One case of perforation was associated with haemorrhage.

Nine gastrectomies were performed.

TABLE III

NUMBER OF CASES ADMITTED ANNUALLY

\begin{tabular}{lccccccccc} 
Year & 1951 & 1952 & 1953 & 1954 & 1955 & 1956 & 1957 & 1958 & $1959(9$ mth.) \\
\hline No. of cases & 2 & 0 & 3 & 0 & 1 & 2 & 3 & 4 & $10=25$
\end{tabular}

necropsy was not obtained in either case so the final diagnosis remains obscure.

In many of these cases there was a history of alcoholic excess, the haematemesis following on persistent vomiting. Phenolphthalein, cantharides, and aspirin were each suspected of being a precipitating factor in three cases.

In this group males $(68 \%)$ predominated over females, and again the majority of the patients $(70 \%)$ were under the age of 40 .

TABLE IV

ACUTE GASTRITIS AND GASTRIC EROSIONS

\begin{tabular}{lcccccc} 
Age (years) & $\begin{array}{l}\text { Under } \\
30\end{array}$ & $30-39$ & $40-49$ & $50-59$ & 60 & Total \\
\hline Bantu males & 8 & 9 & 7 & 3 & 3 & 30 \\
Bantu females & 6 & 5 & 1 & 1 & - & 13 \\
Coloured males & 6 & 6 & 2 & 0 & 1 & 15 \\
Coloured females & 5 & 0 & 1 & 0 & 1 & 7 \\
Total & 25 & 20 & 11 & 4 & 5 & 65
\end{tabular}

CIRRHOSIS AND OESOPHAGEAL VARICES

In this group males again predominated $(72 \%)$; but the tendency is for the older age group to be affected (Table V). Operation was undertaken in five cases. In two cases a portocaval anastomosis was performed and in a further two, transection of the stomach was carried out.

TABLE V

CIRRHOSIS AND OESOPHAGEAL VARICES

\begin{tabular}{|c|c|c|c|c|c|c|}
\hline Age (years) & $\begin{array}{l}\text { Under } \\
30\end{array}$ & $30-39$ & $40-49$ & $50-59$ & $\begin{array}{l}\text { Over } \\
60\end{array}$ & Total \\
\hline Bantu males & 1 & 9 & 1 & 1 & 3 & 15 \\
\hline Bantu females & 3 & 1 & 2 & 1 & - & 7 \\
\hline Coloured males & - & 1 & 2 & 5 & 1 & 9 \\
\hline Coloured females & - & - & - & - & 1 & 1 \\
\hline Total & 4 & 11 & 5 & 7 & 5 & 32 \\
\hline
\end{tabular}

\section{GASTRIC MALIGNANCY AND TUMOURS}

The following are the findings in this group:-

Gastric carcinoma..........4

Leiomyosarcoma .........1

Leiomyoma.............

Reticulum cell sarcoma.......1

OTHER CAUSES

Other causes were:-

Ruptured aortic aneurysm ....2

Oesophageal carcinoma ......1

Oesophageal ulceration........1

Anticoagulation therapy ......1

Chronic intussusception .......1

Gall stones (doubtful aetiology). 1

\section{DISCUSSION}

A comparison of these figures with those in recent British publications reveals marked differences (Avery Jones et al., 1959; Cates, 1959). Whereas over half their cases with haematemesis were caused by peptic ulceration, this association was found in only $18 \%$ of our cases. Peptic ulcer has long been recognized as rare in the non-European, particularly the Bantu (Eagle and Gillman, 1938), though an increasing incidence has been reported recently (Baldachin and Palmer, 1959). The increasing frequency with which haematemesis from this source is being found in this hospital tends to confirm these findings. We have noted no change in the patients 
admitted with regard to race, mentality, standard of education, employment, diet, or any other factor which could possibly account for this increased frequency. The admission rate of patients has increased considerably but not in proportion to the number with peptic ulceration.

Another noteworthy feature is that bleeding in our cases of peptic ulcer occurred mainly in the under-40 age group. This is in marked contradistinction to the findings of Cates in European cases where bleeding occurred very much more commonly in the over-40 age group. Males predominated in the non-European ( 20 out of 25 ) even more than they did in the European series.

The largest group was that labelled 'acute gastritis and gastric erosion'. In contrast to the findings of Cates, which showed an equal incidence of the sexes in his acute ulcer or erosion group, most of our patients were men ( 45 out of 65 ). This is ascribed to the fact that in the majority of our cases the haematemesis followed on continuous vomiting (Mallory-Weiss syndrome) after alcoholic bouts.

We found portal hypertension to be a cause of haematemesis much more frequently than did Avery Jones et al. and Cates in England. Nearly one quarter of our cases fell into this group. In this respect, our figures approximate those from the United States of America. One third of the patients from the Massachusetts General Hospital with massive upper gastrointestinal haemorrhage (Welch, Allen, and Donaldson, 1955) and over $10 \%$ of all cases of haematemesis from the Boston City Hospital (Smythe, Osborne, Zamcheck, Richards, and Madison, 1957) bled from gastro-oesophageal varices. Again in Boston, gastritis is also a common cause of haemorrhage. Alcoholic consumption would appear to be a major factor in determining the similarity of our figures with American figures, and their variance with those from Britain. The prognosis in the non-European with bleeding varices is grave, as it is in the European (Sherlock, 1955). Perhaps the mortality may be lessened by a less conservative approach with more frequent and earlier surgery.
However, very few of our cases would qualify for portocaval anastomosis if the criteria as laid down by Sherlock were followed, namely, adequate liver cell function, serum bilirubin less than $1.5 \mathrm{mg} . \%$, serum albumin level greater than $3 \mathrm{~g} . \%$, and no ascites. In particular it is extremely uncommon for us to encounter a serum albumin level above $3 \mathrm{~g} . \%$ in our cases of cirrhosis. This is not surprising, as the albumin level of the Bantu tends to the lower limit of the normal accepted for the European (Gelfand, 1958). It is felt that better results might be obtained if patients were submitted to surgery forthwith, when bleeding persists despite conservative measures including balloon tamponage. As so few of these patients are suitable candidates for portocaval anastomosis, then transection of the stomach or direct transoesophageal suture of the varices is indicated.

It appears that carcinoma of the stomach is an uncommon cause of gastrointestinal bleeding in the non-European. In only one case was haematemesis a presenting symptom in carcinoma of the oesophagus, though this is a fairly common lesion in the Bantu. No case was associated with diaphragmatic hernia. An interesting feature is that hiatus hernia has never been found in this hospital in the Bantu, and only very rarely in the Coloured.

We wish to thank Dr. G. D. Elliott, Medical Superintendent of Coronation Hospital, for permission to publish this article.

\section{REFERENCES}

Annotation (1959). Brit. med. J., 1, 1462-1463.

Baldachin, B. J., and Palmer, P. E. S. (1959). Ibid, 2, 304.

Cates, J. E. (1959). Ibid, 1, 206-211.

Eagle, P. C., and Gillman, J. (1938). S. Afr. J. med. Sci., 3, 1-6.

Gelfand, M. (1958). Leech (Johannesburg), 28, 49.

Jones, F. Avery, Read, A. E., and Stubbe, J. L. (1959). Brit. med. J., 1, 1138-1142.

Sherlock, S. (1955). Diseases of the Liver and Biliary System. Blackwell, Oxford.

Smythe, C. M., Osborne, M. P., Zamcheck, N., Richards, W. A., and Madison, W. M. (1957). New Engl. J. Med., 256, 441-447.

Welch, C. E., Allen, A. W., and Donaldson, G. A. (1955). Ibid, 252, 921-928. 